\title{
DKK4 Gene
}

National Cancer Institute

\section{Source}

National Cancer Institute. DKK4 Gene. NCI Thesaurus. Code C111881.

This gene is involved in the inhibition of the Wnt signaling pathway. 